\title{
SISTEM INFORMASI GEOGRAFIS (GIS) PADA RUMAH SAKIT DI KABUPATEN LABUHANBATU BERBASIS WEB
}

\author{
Heri Syahputra Ritonga ${ }^{1}$, Deci Irmayani ${ }^{1}$, Ramadhani Pane ${ }^{2}$ \\ ${ }^{1}$ Manajemen Informatika, Fakultas Sains dan Teknologi, Universitas Labuhanbatu \\ ${ }^{2}$ Teknologi Informasi, Fakultas Sains dan Teknologi, Universitas Labuhanbatu \\ email: *herisyahputra261@gmail.com
}

\begin{abstract}
Geographical information system (GIS) is a tool with computer and android systems used to map conditions and events that occur on earth. With the current mapping system's capabilities, it can be used by the community. There are still few people who know the hospitals around them, especially with people outside the district. They have to ask the local community to find out the location of the hospital. With a system designed to provide convenience through determining the hospital location points that are available on the system. The data collection process and methods using the waterfall method. Testing this geographic information system with BlackBox. Someone searches Al-Aziz hospital data by selecting the al-Aziz hospital symbol contained in the system. A detailed menu will appear on the symbol so that it provides information about the hospital address, the schedule for opening and closing of the clinic, the name of the doctor, receiving PBJS health patient services, and the doctor's practice schedule at Al-Aziz Hospital.
\end{abstract}

Keywords: Blackbox Testing; Hospital; Location; Waterfall method; Webgis

\begin{abstract}
Abstrak: Sistem Informasi Geografis (SIG) adalah alat komputer dan sistem android yang digunakan untuk memetakan kondisi dan peristiwa yang terjadi di bumi. Dengan kemampuan sistem pemetaan yang ada saat ini dapat dimanfaatkan oleh masyarakat. Masih sedikit masyarakat yang mengetahui rumah sakit di sekitar mereka, terutama yang berada di luar kabupaten. Mereka harus meminta masyarakat sekitar untuk mengetahui lokasi rumah sakit tersebut. Dengan sistem yang dirancang untuk memberikan kemudahan melalui penentuan titik lokasi rumah sakit yang tersedia dalam sistem. Proses dan metode pengumpulan data menggunakan metode waterfall. Uji sistem informasi geografis ini dengan BlackBox. Seseorang mencari data rumah sakit Al-Aziz dengan memilih simbol rumah sakit al-Aziz yang terdapat dalam sistem. Pada simbol ini akan muncul menu detil sehingga memberikan informasi mengenai alamat rumah sakit, jadwal buka tutup klinik, nama dokter, penerimaan pelayanan pasien kesehatan PBJS, dan jadwal praktek dokter di RS Al-Aziz.
\end{abstract}

Kata kunci: Blackbox Testing; Lokasi; Rumah sakit; Waterfall; Webgis 
Available online at http://jurnal.stmikroyal.ac.id/index.php/jurteksi

\section{PENDAHULUAN}

Sistem Informasi Geografis ini memvisualisasikan data dan menganalisis temuan dengan menggunakan media peta yaitu peta digital[1]. Di daerah Labuhanbatu pencarian lokasi rumah sakit selama ini masyarakat masih menggunakan cara yang kurang efektif dengan cara bertanya kepada masyarakat. Hal ini dapat merugikan ketika kita dalam keadaan genting yang seharus tepat waktu menuju rumah sakit. Hal ini harus segera diselesaikan di daerah Kabupaten Labuhanbatu.

GIS digunakan untuk membantu dalam hal pelayanan umum dalam melihat data rumah sakit karena sistem yang diterapkan ini sangatlah penting dalam sistem informasi. Sehingga dapat mempermudah masyarakat dalam menemukan rumah sakit di daerah Kabupaten Labuhanbatu.

Jarak antar titik pada peta dapat diukur lebih cepat dengan bantuan metode ini. Berbagai peta digital telah dikembangkan untuk menunjukkan lokasi kota-kota di suatu wilayah dan menunjukkan lokasi berbagai fasilitas masyarakat seperti rumah sakit[2]. Memvisualisasikan kita akan lebih mudah mengetahuinya berkat peta digital dengan banyak keunggulan. Nama rumah sakit serta lokasinya. Kami juga dapat mencari informasi tentang dokter spesialis dan pengalamannya[3][4].

Untuk membangun suatu sistem informasi geografis dibutuhkan metode waterfall dan untuk menggambarkan sistem dibangun dengan Unified Modeling Language di terapkan di framework berbasis web yakni codenigter[5][6].

Pemanfaatan GIS sudah mencakup berbagai lini seperti pada transportasi, pariwisata, kesehatan, media dan bahkan monitoring. Dalam pengunaan informasi pemetaan dapat dilakukan dengan beberapa cara diantanya adalah dengan Google Maps dan ArcGIS[7]. Google Maps menyediakan services yang dapat diakses melalui Google Maps API berbasis javascript dan XML[8][9].

Pada Google Maps terdapat lima penyimpanan yang dapat digunakan dalam proses pemetaan yaitu, AdSense Library, Drawing Library, Geometry Library, Places Library, dan Visualization Library, metode yang digunakan dalam sistem ini yakni waterfall. Menurut Pressman model waterfall adalah model klasik yang bersifat berurutan dalam membangun sebuah sistem informasi[10].

\section{METODE}

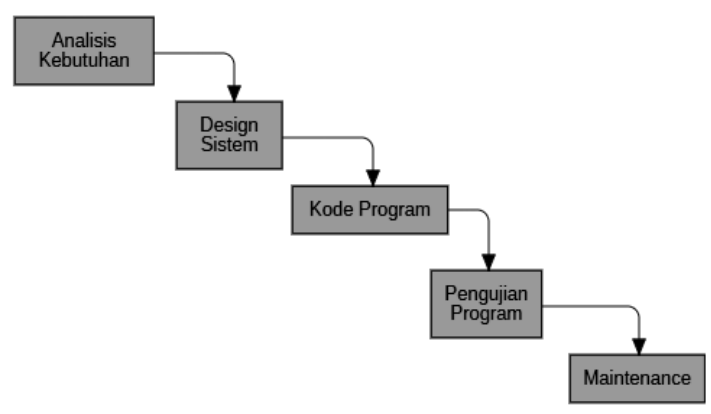

Gambar 1. Sistem Waterfall.

Proses analisa pada webgis rumah sakit di Labuhanbatu dengan melakukan proses observasi meninjau lokasi dan wawancara kepada pihak terkait yakni rumah sakit. Setelah mengetahui apa yang akan dibutuhkan oleh system tersebut tahap yang akan dilanjutkan selanjutnya yakni melakukan perancangan design sistem dan apa-apa yang dibutuhkan oleh sistem baik berupa design input, proses maupun output. Setelah proses analisi dan design yang dilakukan maka proses yang akan selanjutnya dengan membangun sebuah system web gis pada ru- 
mah sakit dengan bantuan tools berupa bahasa programan web dan framework codenigniter serta xampp[11].

Setelah dibangun system webgis pada rumah sakit perlu dilakukan sebuah sistem pengujian yang berfungsi untuk mengetahui seberapa besar kinerja pada system web gis pada rumah sakit yang dibangun, selanjutnya dalam pengujian ini metode yang tepat berupa metode blackbox testing[12].

Maintenance pada fase ini sebagai tahap akhir ketika user atau pengguna dapat dan sudah memahami system web gis pada ruamh sakit yang dibangun baik berupa pelatihan atau pemasangan sistem perlu dilakukan sebuah proses maintenance untuk meningkatkan atau memantau system yang sudah dibangun baik berupa proses backup data dan pemeliharaan hardware pada system tersebut[13].

Unified Modeling Language, atau UML, perangkat lunak untuk menggambarkan aliran dan cara kerja sistem serta fungsi, tujuan, dan mekanisme kontrolnya. Use Case diagram, Class diagrams, Sequence diagram, dan metode perancangan sistem informasi yang dapat digunakan untuk perancangan sistem.[14][15]. Codeigniter memiliki konsep M-V-C (Model-View-Controller) yaitu konsep untuk membatasi antara tampilan web dan control akses. Kode PHP, Mysql, Javascript, dan kueri CSS semuanya dapat dipisahkan, membuat ukuran file lebih kecil dan lebih dapat digunakan untuk perbaikan dan pemeliharaan. [16][17].

\section{HASIL DAN PEMBAHASAN}

\section{Analisis Kebutuhan.}

Proses analisa pada web gis rumah sakit di Labuhanbatu dengan melakukan proses observasi meninjau lokasi dan wawancara kepada pihak terkait yakni rumah sakit.

\section{Use Case Diagram.}

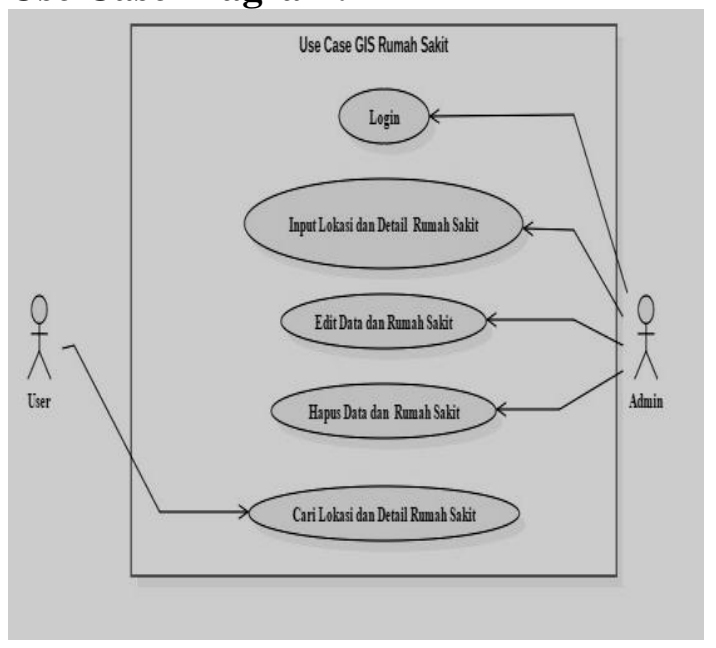

Gambar 2. Use Case Diagram Webgis.

Gambar 2 proses pembuatan use case diagram login dan akses user, diagram ini menjelaskan seorang actor yang berupa admin melakukan proses login untuk masuk kedalam sistem. Proses login ini akan menampilkan menu-menu meliputi menu utama yaitu menu admin untuk input, edit,dan hapus, untuk user hanya bias melihat data yang ada dirumah sakit tujuan dan cari lokasi rumah sakit[18].

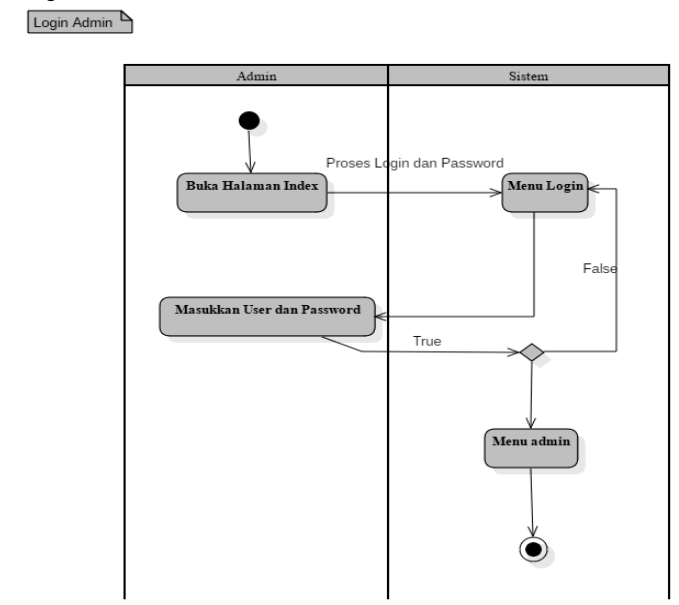

Gambar 3. Activity Diagram Login.

Gambar 3 Admin mengakses ke halaman 
Available online at http://jurnal.stmikroyal.ac.id/index.php/jurteksi

index Sistem menampilkan halaman utama login, Admin mengisi username dan password. Sistem mengecek username dan password benar atau tidak, Username dan password benar maka menu admin, dan apabila salah akan kembali ke menu login.

\section{Sequence Diagram Login.}

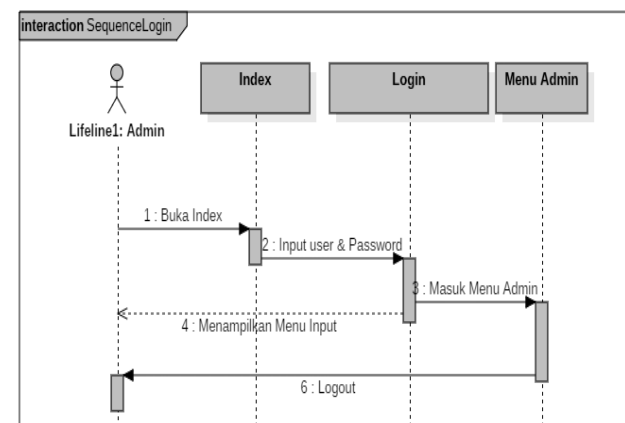

Gambar 4. Sequence Diagram Admin

Gambar 4 dimana admin membuka index sistem, kemudian mengisi username dan password dan login, sistem mengecek username dan password benar atau tidak, jika username dan password benar maka menu admin, apabila username dan password salah maka akan dikembalikan ke fom input username dan password.

\section{Sequence Diagram User.}

interaction SequenceDiagraml

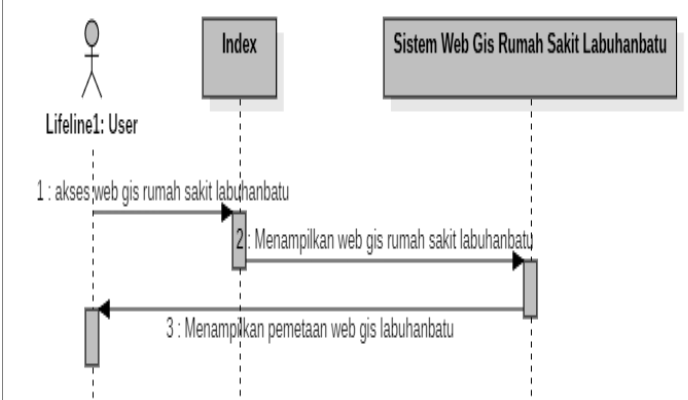

Gambar 5. Sequence Diagram User

Gambar 5 user hanya dapat mengakses index halaman dan hanya melihat pemetaan beserta data rumah sakit yang sesuai dengan kondisi pasien.

\section{Class Diagram.}

Class Diagram ini terdiri dari Admin, User, Data. Di dalam Class ini memiliki saling keterkaitan secara tersystem dah dari gambar yang kita lihat dimana adminlah yang mengatur kerja system dan mengelolahdi data dandi data menyalurkan hasil inputan admin ke halam utama.

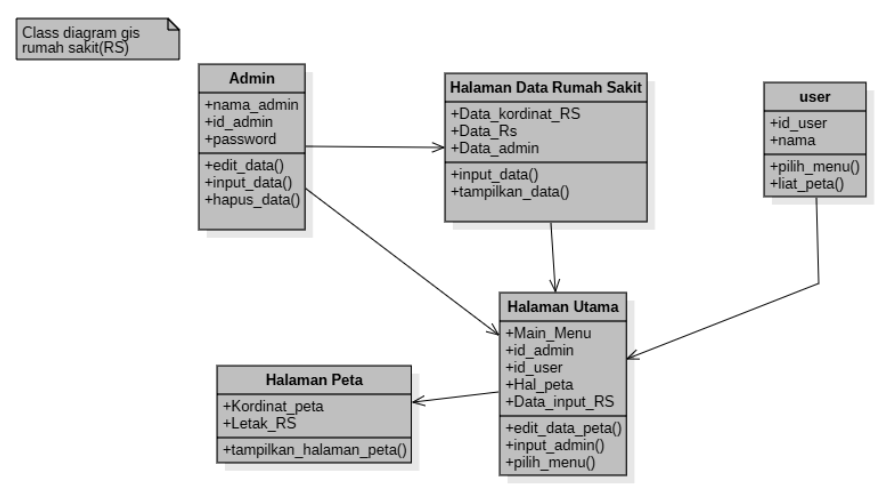

Gambar 6. Class Diagram

\section{Desain Sistem}

Perancangan design system dan apa-apa yang dibutuhkan oleh system baik berupa design input, proses maupun output.

Halaman Utama Menu Login Admin.
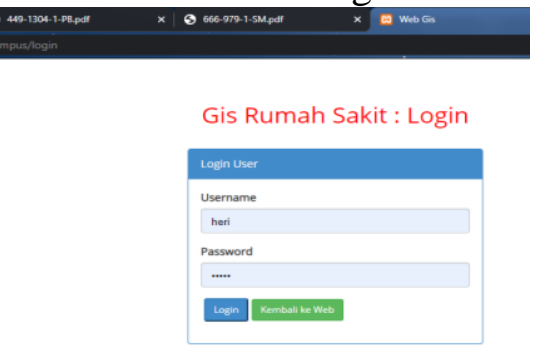

Gambar 6. Halaman Admin

Gambar 6 halaman utama login admin yang di gunakan untuk masuk ke halaman admin.

Halaman Utama Menu Login Admin. 
Available online at http://jurnal.stmikroyal.ac.id/index.php/jurteksi

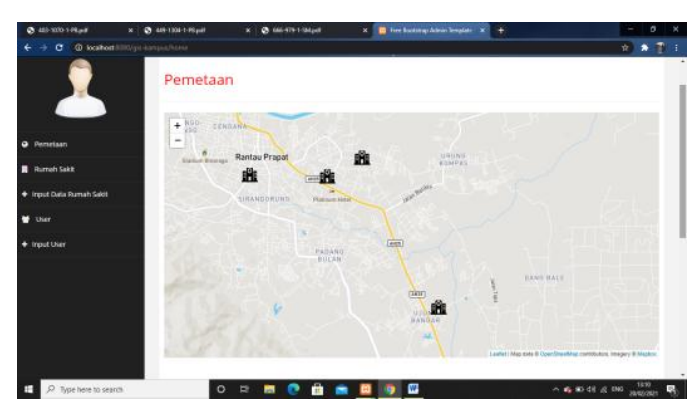

Gambar 7. Halaman Admin.

Halaman admin adalah halaman utama untuk admin yang digunakan untuk input, edit dan hapus data.

Index Webgis Rumah Sakit

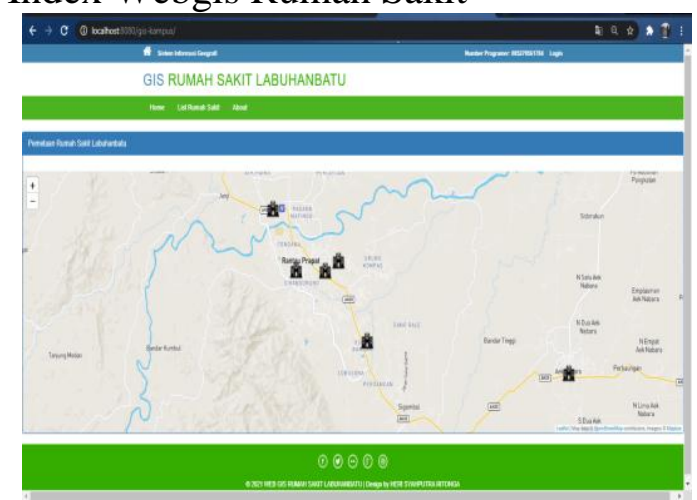

Gambar 8. Halaman Utama Web.

Gambar 8 menu utama tempat rumah sakit (home) yang ditujukan untuk user dimana user nanti dapat melihat, letak rumah sakit di Labuhanbatu dan berserta info tentang rumah sakitnya.

Halaman Detail dari Rumah Sakit.

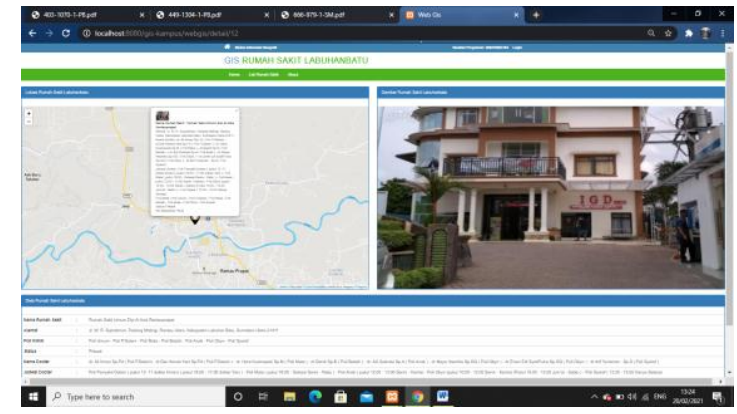

Gambar 9. Halaman Detail.

Gambar 9 user dapat melihat data keseluruhan dari web rumah sakit dilabuhanbatu, misalnya nama dokter yang hadir dan poli klinik.

\section{Halaman Pencarian Rumah Sakit}

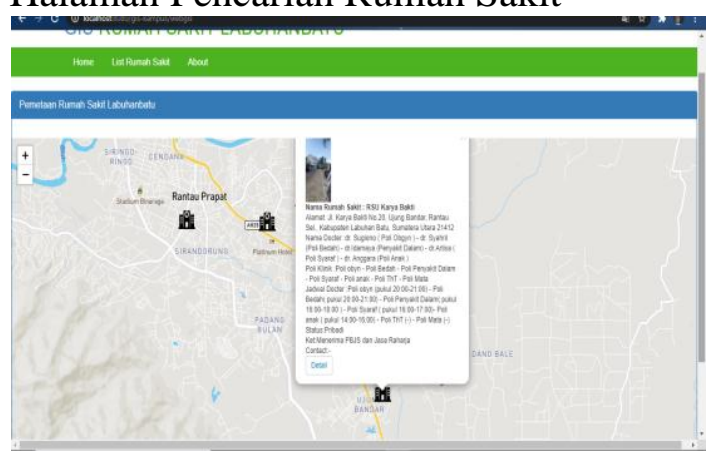

Gambar 10. Halaman Pencarian.

Pada halaman ini kita dapat melihat dan memilih rumah sakit yang ada dilabuhanbatu.

Pada gambar 11 merupakan halaman informasi mengenai Rumah Sakit pada halaman user.

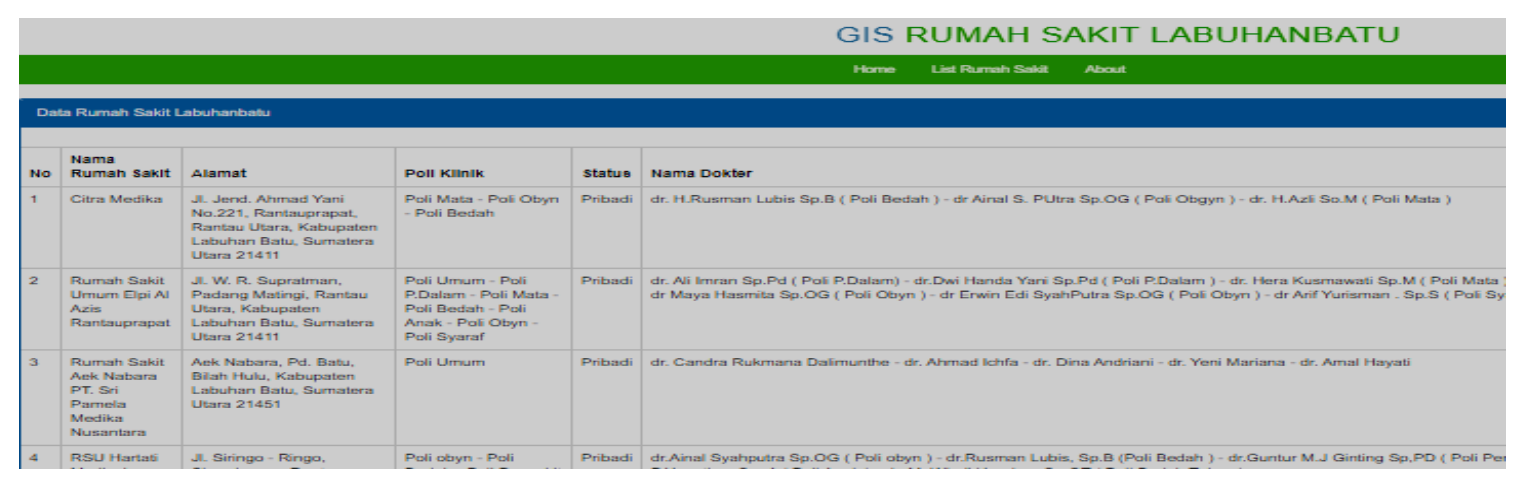

Gambar 11. Halaman Info Rumah sakit 
JURTEKSI (Jurnal Teknologi dan Sistem Informasi)

Vol. VII No. 2, April 2021, hlm. 227- 235

DOI: https://doi.org/10.33330/jurteksi.v7i2.1089

Available online at http://jurnal.stmikroyal.ac.id/index.php/jurteksi
ISSN 2407-1811 (Print)

ISSN 2550-0201 (Online)

\section{Pengujian Program dengan Blackbox Testing}

Tabel 1. Tabel Pengujian BlackBox Testin

\begin{tabular}{|c|c|c|c|c|}
\hline $\begin{array}{l}\text { Skenario } \\
\text { Pengujian }\end{array}$ & Test Case & Hasil yang Diharapkan & Hasil Pegujian & Kesimpulan \\
\hline Tombol home & $\begin{array}{l}\text { Klik tombol } \\
\text { home }\end{array}$ & $\begin{array}{l}\text { Dapat menampilkan home } \\
\text { web }\end{array}$ & $\begin{array}{l}\text { Sesuai } \\
\text { Yang diharapkan }\end{array}$ & Valid \\
\hline $\begin{array}{l}\text { Tombol } \\
\text { list rumah sakit }\end{array}$ & $\begin{array}{l}\text { Klik tombol list } \\
\text { rumah sakit }\end{array}$ & $\begin{array}{l}\text { Dapat menampilkan list data } \\
\text { rumah sakit }\end{array}$ & $\begin{array}{l}\text { Sesuai } \\
\text { yang diharapkan }\end{array}$ & Valid \\
\hline Tombol about & $\begin{array}{l}\text { Klik tombol } \\
\text { about }\end{array}$ & Dapat menampilkan about & $\begin{array}{l}\text { Sesuai } \\
\text { yang diharapkan }\end{array}$ & Valid \\
\hline $\begin{array}{l}\text { Tombol } \\
\text { zoom in/out }\end{array}$ & $\begin{array}{l}\text { Klik tombol } \\
\text { zoom in/out }\end{array}$ & $\begin{array}{l}\text { Dapat memperdekat dan } \\
\text { mmeperjauh lokasi }\end{array}$ & $\begin{array}{l}\text { Sesuai } \\
\text { yang diharapkan }\end{array}$ & Valid \\
\hline Icon rumah sakit & Klik icon & $\begin{array}{l}\text { Dapat menampilkan info ten- } \\
\text { tang rumah sakit }\end{array}$ & $\begin{array}{l}\text { Sesuai } \\
\text { yang diharapkan }\end{array}$ & Valid \\
\hline Tombol detail & $\begin{array}{l}\text { Klik detail pada } \\
\text { icon rumah sakit }\end{array}$ & $\begin{array}{l}\text { Dapat menampilkan halaman } \\
\text { web yang berisikan detail ru- } \\
\text { mah sakit al-aziz }\end{array}$ & $\begin{array}{l}\text { Sesuai } \\
\text { yang diharapkan }\end{array}$ & Valid \\
\hline Menu login & Klik login & $\begin{array}{l}\text { Akan megarahkan login untuk } \\
\text { admin }\end{array}$ & $\begin{array}{l}\text { Sesuai } \\
\text { yang diharapkan }\end{array}$ & Valid \\
\hline Tombol login & Klik tombol & $\begin{array}{l}\text { Jika user name dan password } \\
\text { benar maka akan otomatis } \\
\text { menuju halaman admin }\end{array}$ & $\begin{array}{l}\text { Sesuai } \\
\text { yang diharapkan }\end{array}$ & Valid \\
\hline Tombol login & Klik tombol & $\begin{array}{l}\text { Jika user name dan password } \\
\text { benar maka akan otomatis } \\
\text { menuju halaman admin }\end{array}$ & $\begin{array}{l}\text { Sesuai } \\
\text { yang diharapkan }\end{array}$ & Valid \\
\hline Menu pemetaan & $\begin{array}{l}\text { Klik } \\
\text { menu pemetaan }\end{array}$ & $\begin{array}{l}\text { Akan menampilkan peta ru- } \\
\text { mah sakit pada halaman ad- } \\
\text { min }\end{array}$ & $\begin{array}{l}\text { Sesuai } \\
\text { yang diharapkan }\end{array}$ & Valid \\
\hline Menu rumah sakit & Klik menu & $\begin{array}{l}\text { Akan menampilkan data ru- } \\
\text { mah sakit dan tombol ed- } \\
\text { it/hapus pada halaman admin }\end{array}$ & $\begin{array}{l}\text { Sesuai } \\
\text { yang diharapkan }\end{array}$ & Valid \\
\hline Tombol edit & Klik tombol edit & $\begin{array}{l}\text { Akan menampilkan ke hala- } \\
\text { man edit }\end{array}$ & $\begin{array}{l}\text { Sesuai } \\
\text { yang diharapkan }\end{array}$ & Valid \\
\hline Tombol hapus & $\begin{array}{l}\text { Klik } \\
\text { tombol hapus }\end{array}$ & Akan menghapus data & $\begin{array}{l}\text { Sesuai } \\
\text { yang diharapkan }\end{array}$ & Valid \\
\hline
\end{tabular}

Tabel 2. Tabel Pengujian BlackBox Testing

\begin{tabular}{lllll}
\hline $\begin{array}{l}\text { Skenario } \\
\text { Pengujian }\end{array}$ & Test Case & \multicolumn{1}{c}{ Hasil yang Diharapkan } & Hasil Pegujian & Kesimpulan \\
\hline $\begin{array}{l}\text { Menu } \\
\text { input rumah sakit }\end{array}$ & $\begin{array}{l}\text { Klik } \\
\text { menunya }\end{array}$ & $\begin{array}{l}\text { Akan menampikan peta rumah } \\
\text { sakit dan form untuk diisi } \\
\text { dengan data rumah sakit yang } \\
\text { akan di input }\end{array}$ & $\begin{array}{l}\text { Sesuai } \\
\text { yang diharapkan }\end{array}$ & Valid \\
\hline Menu user & $\begin{array}{l}\text { Klik } \\
\text { menunya }\end{array}$ & Akan menampilkan data user & $\begin{array}{l}\text { Sesuai } \\
\text { yang diharapkan }\end{array}$ & Valid \\
\hline Menu input user & Klik menu & $\begin{array}{l}\text { Menampilkan form pengisian } \\
\text { user }\end{array}$ & $\begin{array}{l}\text { Sesuai } \\
\text { yang diharapkan }\end{array}$ & Valid \\
\hline Tombol Logout & Klik tom- & $\begin{array}{l}\text { Akan mengarahkan kembali ke } \\
\text { halaman tunuk login dan kem- } \\
\text { bali ke halaman utama use }\end{array}$ & $\begin{array}{l}\text { Sesuai } \\
\text { yang diharapkan }\end{array}$ & Valid \\
& & & & \\
\hline
\end{tabular}


DOI: https://doi.org/10.33330/jurteksi.v7i2.1089

Available online at http://jurnal.stmikroyal.ac.id/index.php/jurteksi

\section{SIMPULAN}

Webgis rumah sakit di kabupaten Bilahulu memberikan kemudahan bagi masyarakat yang mencari lokasi rumah sakit. Dengan adanya peta digital ini masyarakat dapat mengetahui rumah sakit yang akan dicari sesuai informasi. Dapat mengetahui nama dokter, informasi poli klinik dan titik koordinat rumah sakit dan masyarakat dapat mengetahui jadwal dokter. Dengan sistem informasi geografis diharapkan dapat mengurangi kesalahan informasi mengenai data rumah sakit. Dan sebagai suatu sistem sudah di uji dengan black box agar tidak ada bug atau tombol operasi yang tidak berfungsi.

\section{DAFTAR PUSTAKA}

[1] F. I. Aksa, "Geografi dalam Perspektif Filsafat Ilmu," Maj. Geogr. Indones., vol. 33, no. 1, p. 43, 2019, doi: 10.22146/mgi.35682.

[2] D. W. Nugraha, "Perancangan Sistem Informasi Geografis Menggunakan Peta Digital," $J$. Ilm. Foristek, vol. 2, no. 1, pp. 117-125, 2012.

[3] A. Kahfi and M. Sarjan, "Implementasi Peta Digital Untuk Smart Village (Studi Kasus Desa Tammangalle, Polewali Mandar)," J. Ilm. Ilmu Komput., vol. 6, no. 1, pp. 13-18, 2020.

[4] F. P. Putra and D. Danuri, "Peta Digital Demografi Penduduk Tingkat Desa Berbasis Web Menggunakan Google Maps API," Digit. Zo. J. Teknol. Inf. dan Komun., vol. 9, no. 1, pp. 33-41, 2018 , doi: 10.31849/digitalzone.v9i1.961.
[5] M. Destiningrum and Q. J. Adrian, "Sistem Informasi Penjadwalan Dokter Berbassis Web Dengan Menggunakan Framework Codeigniter (Studi Kasus: Rumah Sakit Yukum Medical Centre)," J. Teknoinfo, 2017, doi: 10.33365/jti.v11i2.24.

[6] B. Tujni and H. Hutrianto, "Pengembangan Perangkat Lunak Monitoring Wellies Dengan Metode Waterfall Model," J. Ilm. Matrik, vol. 22, no. 1, pp. 122130, 2020, doi: 10.33557/jurnalmatrik.v22i1.862.

[7] M. R. M. \& H. Kurniawan, "Sistem Informasi Geografis Pemetaan Rumah Sakit di Kota Pontianak," Enter, pp. 478-489, 2017.

[8] P. N. Bali, "Paket Program Aplikasi ArcGIS Analys dan Mapping," no. October, 2020.

[9] M. Silalahi, "Perbandingan Performansi Database Mongodb Dan Mysql Dalam Aplikasi File Multimedia Berbasis Web," Comput. Based Inf. Syst. J., vol. 6, no. 1, p. 63, 2018, doi: 10.33884/cbis.v6i1.574.

[10] C. M. Cahyadi and G. Susanto, "Rancang Bangun Sistem Informasi Bimbingan Konseling Di SMK Tamansiswa Mojokerto Berbasis Web Menggunakan Model Waterfall," RAINSTEK J. Terap. Sains ..., vol. 2, no. 1, pp. 61-70, 2020, [Online]. Available: http://ejournal.unikama.ac.id/index .php/jtst/article/view/4154.

[11] E. Ratnasari, "Pengertian Dan Fungsi Xampp," Ilmuti.Org, 2018.

[12] M. Rizka, A. Amri, H. Hendrawaty, and M. Mahdi, "Analisis Dan Perancangan Sistem Informasi Tracer Study Berbasis 
WEB," J. Infomedia, vol. 3, no. 2, 2018, doi: 10.30811/jim.v3i2.716.

[13] D. Y. Prasetyo, "Implementasi Geographic Information System (Gis) Penentuan Tampat Ibadah Masjid Di Kecamatan Kempas Kabupaten Indragiri Hilir Provinsi Riau," Sistemasi, vol. 8, no. 1, p. 10, 2019, doi: 10.32520/stmsi.v8i1.403.

[14] S. S. Vallery, Happy Novita, "Jurnal Mantik," J. Mantik, vol. 3, no. January, pp. 31-38, 2019.

[15] M. F. A. Tansa Trisna Astono Putri, Mhd. Dominique Mendoza, "Jurnal Mantik," J. Mantik, vol. 3, no. January, pp. 31-38, 2019.

[16] I. R. Munthe, "Perancangan Sistem Informasi Pengarsipan Data Penduduk Pada Kantor Camat Bilah Hulu Kabupaten Labuhan Batu Dengan Metode System Develovment Life Cycle (Sdlc)," J. Inform., vol. 5, no. 1, pp. 22-31, 2019, doi: 10.36987/informatika.v5i1.666.

[17] H. Larasati and S. Masripah, "Analisa Dan Perancangan Sistem Informasi Pembelian Grc Dengan Metode Waterfall," J. Pilar Nusa Mandiri, 2017.

[18] U. Rusmawan, "Pengertian Use Case Diagram," in Teknik Penulisan Tugas Akhir dan Skripsi Pemrograman, 2019.

[1] F. I. Aksa, "Geografi dalam Perspektif Filsafat Ilmu," Maj. Geogr. Indones., vol. 33, no. 1, p. 43, 2019, doi: 10.22146/mgi.35682.

[2] D. W. Nugraha, "Perancangan Sistem Informasi Geografis Menggunakan Peta Digital," $J$. Ilm. Foristek, vol. 2, no. 1, pp. 117-125, 2012.
[3] A. Kahfi and M. Sarjan, "Implementasi Peta Digital Untuk Smart Village (Studi Kasus Desa Tammangalle, Polewali Mandar)," J. Ilm. Ilmu Komput., vol. 6, no. 1, pp. 13-18, 2020.

[4] F. P. Putra and D. Danuri, "Peta Digital Demografi Penduduk Tingkat Desa Berbasis Web Menggunakan Google Maps API," Digit. Zo. J. Teknol. Inf. dan Komun., vol. 9, no. 1, pp. 33-41, 2018, doi: 10.31849/digitalzone.v9i1.961.

[5] M. Destiningrum and Q. J. Adrian, "Sistem Informasi Penjadwalan Dokter Berbassis Web Dengan Menggunakan Framework Codeigniter (Studi Kasus: Rumah Sakit Yukum Medical Centre)," J. Teknoinfo, 2017, doi: 10.33365/jti.v11i2.24.

[6] B. Tujni and H. Hutrianto, "Pengembangan Perangkat Lunak Monitoring Wellies Dengan Metode Waterfall Model," J. Ilm. Matrik, vol. 22, no. 1, pp. 122130, 2020, doi: 10.33557/jurnalmatrik.v22i1.862.

[7] M. R. M. \& H. Kurniawan, "Sistem Informasi Geografis Pemetaan Rumah Sakit di Kota Pontianak," Enter, pp. 478-489, 2017.

[8] P. N. Bali, "Paket Program Aplikasi ArcGIS Analys dan Mapping," no. October, 2020.

[9] M. Silalahi, "Perbandingan Performansi Database Mongodb Dan Mysql Dalam Aplikasi File Multimedia Berbasis Web," Comput. Based Inf. Syst. J., vol. 6, no. 1, p. 63, 2018, doi: 10.33884/cbis.v6i1.574.

[10] C. M. Cahyadi and G. Susanto, "Rancang Bangun Sistem 
Informasi Bimbingan Konseling Di SMK Tamansiswa Mojokerto Berbasis Web Menggunakan Model Waterfall," RAINSTEK J. Terap. Sains ..., vol. 2, no. 1, pp. 61-70, 2020, [Online]. Available: http://ejournal.unikama.ac.id/index .php/jtst/article/view/4154.

[11] E. Ratnasari, "Pengertian Dan Fungsi Xampp," Ilmuti.Org, 2018.

[12] M. Rizka, A. Amri, H. Hendrawaty, and M. Mahdi, "Analisis Dan Perancangan Sistem Informasi Tracer Study Berbasis WEB," J. Infomedia, vol. 3, no. 2, 2018, doi: 10.30811/jim.v3i2.716.

[13] D. Y. Prasetyo, "Implementasi Geographic Information System (Gis) Penentuan Tampat Ibadah Masjid Di Kecamatan Kempas Kabupaten Indragiri Hilir Provinsi Riau," Sistemasi, vol. 8, no. 1, p. 10, 2019, doi: 10.32520/stmsi.v8i1.403.

[14] S. S. Vallery, Happy Novita,
"Jurnal Mantik," J. Mantik, vol. 3, no. January, pp. 31-38, 2019.

[15] M. F. A. Tansa Trisna Astono Putri, Mhd. Dominique Mendoza, "Jurnal Mantik," J. Mantik, vol. 3, no. January, pp. 31-38, 2019.

[16] I. R. Munthe, "Perancangan Sistem Informasi Pengarsipan Data Penduduk Pada Kantor Camat Bilah Hulu Kabupaten Labuhan Batu Dengan Metode System Develovment Life Cycle (Sdlc)," J. Inform., vol. 5, no. 1, pp. 22-31, 2019, doi: 10.36987/informatika.v5i1.666.

[17] H. Larasati and S. Masripah, "Analisa Dan Perancangan Sistem Informasi Pembelian Grc Dengan Metode Waterfall," J. Pilar Nusa Mandiri, 2017.

[18] U. Rusmawan, "Pengertian Use Case Diagram," in Teknik Penulisan Tugas Akhir dan Skripsi Pemrograman, 2019. 